\title{
Retraction: Role of senescence and mitotic catastrophe in cancer therapy
}

Richa Singh, Jasmine George and Yogeshwer Shukla*

\section{Retraction}

This article [1] is retracted as it contains large amount of text that has been duplicated from other articles previously published. We apologize to all affected parties for the inconvenience caused.

Received: 27 April 2012 Accepted: 15 May 2012

Published: 15 May 2012

\section{References}

1. Singh R, George J, Shukla Y: Role of senescence and mitotic catastrophe in cancer therapy. Cell Division 2010, 5:4.

Submit your next manuscript to BioMed Central and take full advantage of:

- Convenient online submission

- Thorough peer review

- No space constraints or color figure charges

- Immediate publication on acceptance

- Inclusion in PubMed, CAS, Scopus and Google Scholar

- Research which is freely available for redistribution

Submit your manuscript at

www.biomedcentral.com/submit

() Biomed Central 